Advances in Gene Technology: The Genome and Beyond -

Structural Biology for Medicine (Proceedings of the 2002 Miami

Nature Biotechnology Winter Symposium)

TheScientificWorld 2002, 2(S2), 33-34

ISSN 1532-2246; DOI 10.1100/tsw.2002.17

\title{
AUTOMATED PROTEIN PURIFICATION FOR STRUCTURAL STUDIES
}

\author{
Hans O. Andersson, Pär Eklund, Markus Galin, Lotta Hedqvist, Pia Liljedahl, Christine \\ Markeland, Thomas Pless, Jill A. Sigrell*, and Karin Torstenson \\ Amersham Biosciences, Björkgatan 30, SE-751 84 Uppsala, Sweden \\ *jill.sigrell@eu.amershambiosciences.com
}

INTRODUCTION. Structural genomics, also known as structural proteomics, aims to resolve protein functions on a large scale[1]. To determine structures using either X-ray crystallography or NMR, fairly large amounts (>10 mg) of target proteins (which are pure, homogenous, and concentrated) are usually required. A robust and easy-to-use protein purification scheme that can automatically produce numerous proteins in a desired form would increase the throughput of structure determination[2]. Using a new strategy and optimized methods, a newly configured ÄKTAexplorer ${ }^{\mathrm{TM}}$ (ÄKTA is a trademark of the Amersham Biosciences group. Amersham and Amersham Biosciences are trademarks of Amersham Plc. (C) Amersham Biosciences AB 2001 All rights reserved.) 100 can perform automated two-step purification of up to six different proteins serially using two different purification schemes.

METHODS. Ten different soluble and well-expressed recombinant proteins tagged with either (His) 6 or Glutathione S-transferase (GST) were produced in Escherichia coli. These proteins, with varying molecular weights (20-70 kD) and pIs (5.1-9.2), were purified using two different purification schemes: (1) affinity chromatography followed by gel filtration and (2) affinity chromatography followed by an intermediate desalting step prior to ion exchange chromatography.

Each sample was first applied and washed on an affinity column matching the affinity tag. By using one column for each protein, the different proteins could be captured one by one in a quick serial mode, thereby minimizing contact with proteases present in the homogenized E. coli extracts. Automation of the chosen purification schemes was achieved by using the added sample loops as reinjection devices in combination with step-elution. The eluted protein from one column (affinity or desalting) was directed to a sample loop before being injected to the next column. 
RESULTS AND DISCUSSION. Production of six different pure proteins could be achieved within $12 \mathrm{~h}$ using scheme A and four proteins within $4 \mathrm{~h}$ using scheme B. Purification of all proteins using any of the purification schemes resulted in up-to-50 $\mathrm{mg}$ of $90-99 \%$ pure protein. For most proteins, ion exchange chromatography removed impurities to a higher degree than gel filtration. However, the ability of gel filtration to remove aggregates often makes it a valuable final step in preparing homogenous protein samples for structural studies. With this new configuration, the researcher saves time compared to the same chromatography steps performed in a nonautomated manner.

ACKNOWLEDGEMENTS. Amersham Biosciences is grateful to Structural GenomiX for providing several of the tested His-tagged proteins.

\section{REFERENCES}

1. Structural genomics supplement (2000) Nat. Struct. Biol. 7, 927-994.

2. Lesley, S.A. (2001) Prot. Express. Purif. 22, 159-164. 

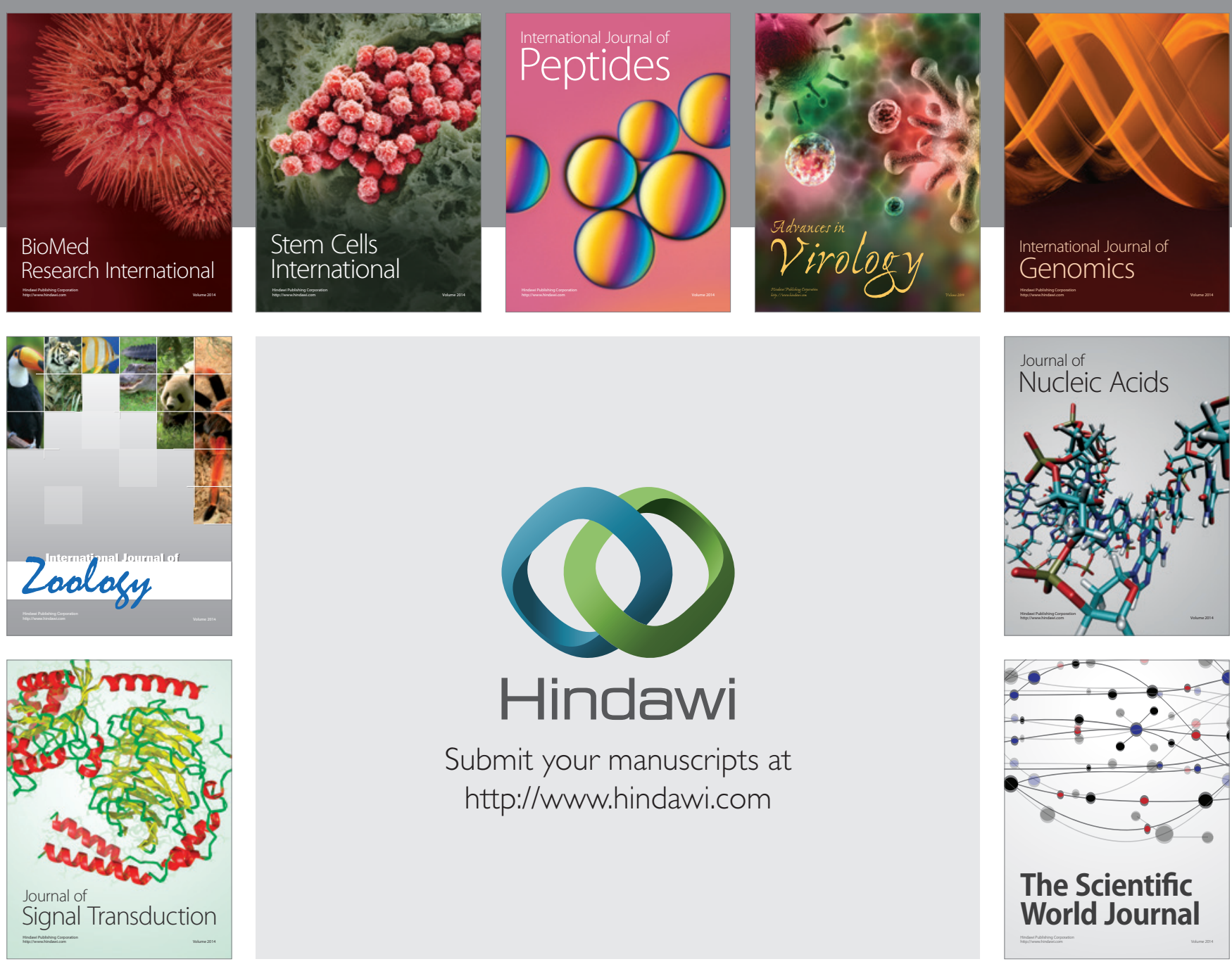

Submit your manuscripts at

http://www.hindawi.com
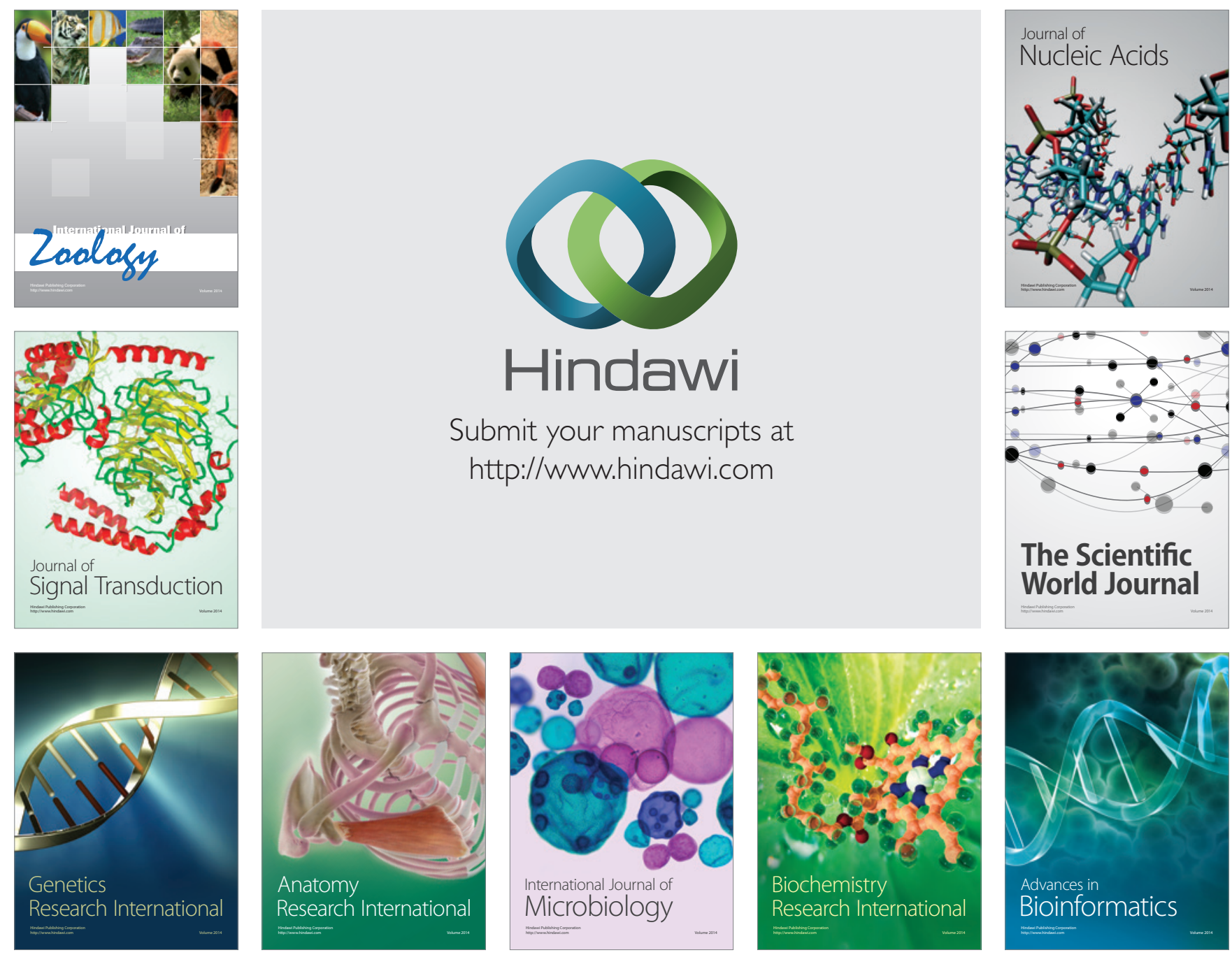

The Scientific World Journal
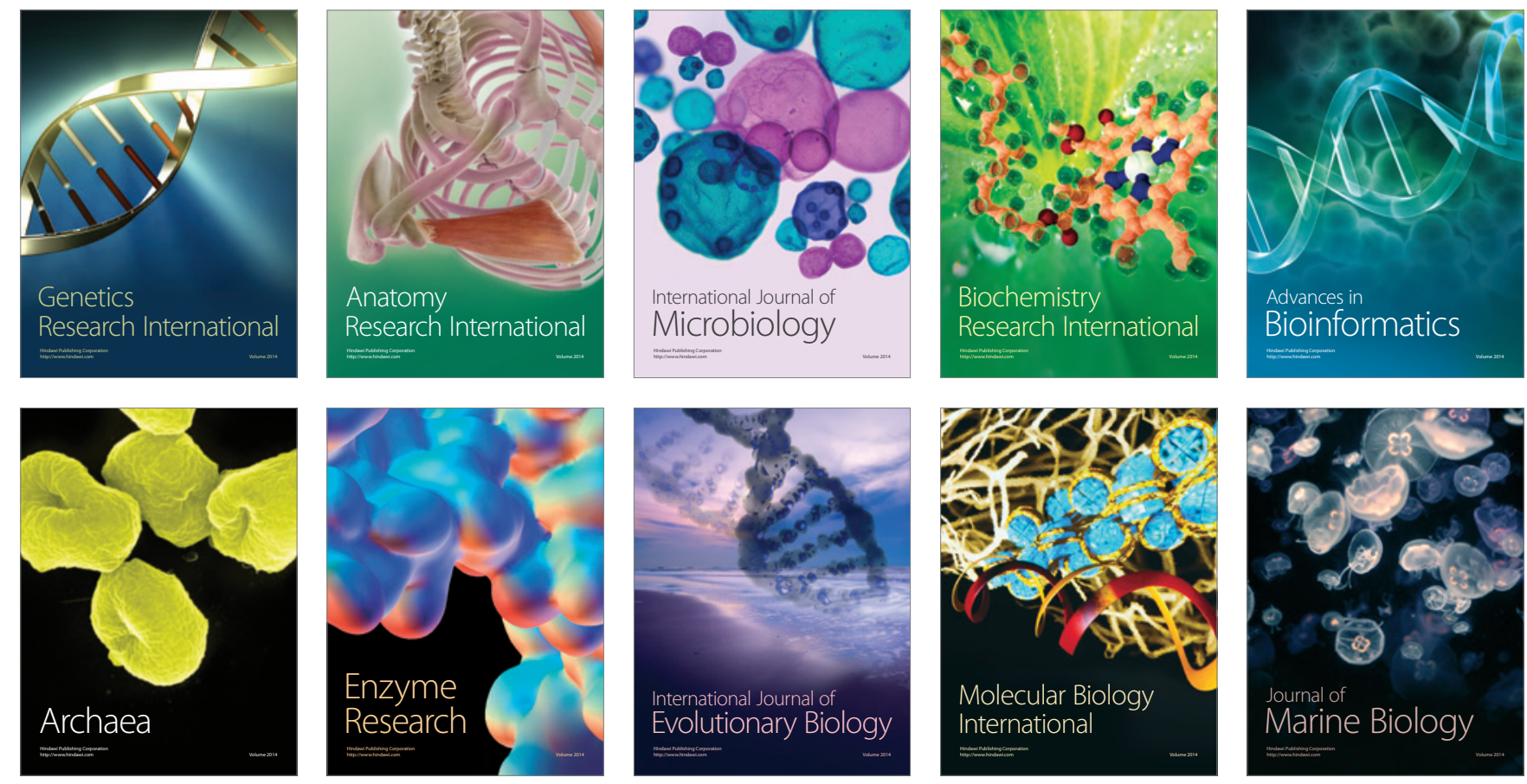